\title{
PENGEMBANGAN DESAIN HUNIAN SEMENTARA UNTUK KORBAN GEMPA LOMBOK
}

\author{
Jauhar Fajrin'), Muhammad Muchlis ${ }^{2)}$, Yogi Rosita Tandean ${ }^{3)}$ \\ 1,2,3)Jurusan Teknik Sipil, Fakultas Teknik, Universitas Mataram \\ Jl. Majapahit No. 62 Mataram, NTB. \\ Email: jauhar.fajrin@unram.ac.id
}

\begin{abstract}
ABSTRAK
Rangkaian gempa panjang selama hampir satu bulan dengan goncangan terbesar mencapai 7 SR telak menghancurkan banyak rumah yang ada di wilayah Lombok dan Sumbawa. Saat kembali dari pengungsian mereka memerlukan hunian sementara terlebih dahulu sembari membangun kembali rumahnya. Terdapat banyak pilihan desain dan model hunian sementara yang telah dikembangkan sebelumnya. Namun demikian, untuk membuat sebuah hunian sementara yang sesuai dengan kebutuhan masyarakat di lokasi bencana membutuhkan pemahaman mengenai karateristik manusia maupun alam dan lingkungan setempat. Beberapa hal yang perlu dipertimbangkan adalah dampak yang ditimbulkan terhadap lingkungan apabila menggunakan bahan yang berasal dari alam. Desain yang dikembangkan berbasis pada konsep rumah lumbung dengan bahan bambu dan spandek-plywood. Konsep pertama adalah huntara lumbung bambu yang mengadopsi rumah tradisional Lombok yang berbentuk lumbung menggunakan bahan kayu usuk dan pipa paralon dengan dinding anyaman bambu. Konsep kedua juga berbasis rumah lumbung, tetapi menggunakan bahan spandek sebagai material yang dominan untuk bagian atapnya dan plywood sebagai dinding dan pintu. Kedua konsep hunian sementara telah berhasil didesain, dibangun dan diaplikasikan.
\end{abstract}

Kata Kunci: hunian sementara, bambu, baham alam, rumah lumbung

\begin{abstract}
A long series of earthquakes that lasted for almost a month with the biggest shock reaching 7 SR completely destroyed most of the houses in parts of Lombok and Sumbawa. Many residents were forced to evacuate because their homes entirely devastated. Some residents have returned to their homes, but many also have no place to return. So they need temporary shelter while rebuilding their houses gradually. There are many choices of designs that have been developed before. However, designing a temporary shelter that is truly in accordance with the needs of the community at the disaster site requires a comprehensive understanding of the local human characteristics and nature as well as the local environment. Including things that must be considered is the impact on the environment if the design involves locally available nature material. The design concept was based on the concept of a barn house with bamboo and spandex-plywood materials. The first concept is a bamboo barn shelter which adopts a traditional Lombok house with woven bamboo walls. The second concept is also based on traditional Lombok houses, but uses a different material which is spandek as the dominant material for the roof and plywood as the walls and doors. Both temporary shelter concepts have been successfully designed, built and applied.
\end{abstract}

Key words: temporary shelter, bamboo, nature material, barn house 


\section{PENDAHULUAN}

Rangkaian gempa panjang selama hampir satu bulan dengan goncangan terbesar mencapai 7 SR telak memporak-porandakan sebagian besar rumah yang ada di sebagian wilayah Lombok dan Sumbawa, khususnya di wilayah Lombok Utara dan Timur. Sebagian besar warga terpaksa harus mengungsi karena rumah mereka sudah rata dengan tanah. Saat ini sebagian warga sudah mulai kembali kerumahnya, namun banyak juga yang sama sekali tidak mempunyai tempat untuk kembali. Sehingga mereka memerlukan hunian sementara (huntara) terlebih dahulu sembari membangun kembali rumahnya secara perlahan. Terdapat banyak pilihan desain dan model hunian sementara yang telah dikembangkan oleh berbagai pihak terkait dengan gempa yang terjadi sebelumnya diberbagai belahan dunia. Namun demikian, untuk membuat sebuah hunian sementara yang benar-benar sesuai dengan kebutuhan masyarakat di lokasi bencana membutuhkan pemahaman yang cukup mendalam mengenai karateristik manusia maupun alam dan lingkungan setempat. Pemahaman mengenai karateristik manusia dibutuhkan agar hunian yang dibuat sebisa mungkin cukup dekat dan menyatu dengan kultur masyarakat setempat sehingga mereka merasa tidak asing menggunakannya. Sementara pemahaman mengenai alam dan lingkungan berhubungan dengan ketersedian bahan dan kesiapan manusia untuk membuatnya. Termasuk hal yang harus dipertimbangkan adalah mengenai dampak yang ditimbulkan terhadap lingkungan apabila desain yang dikembangkan terlalu mengeksploitasi bahan yang berasal dari alam. Artikel ini membahas mengenai konsep hunian sementara yang dikembangkan berbasis kearifan lokal masyarakat Lombok yang diperuntukan bagi korban gempa Lombok tahun 2018.

\section{TINJAUAN PUSTAKA}

Rohwerder (2016) menjelaskan bahwa hunian sementara adalah salah satu factor yang sangat menentukan keberhasilan sebuah program penanganan pasca bencana. Abulnour (2014) mengembangkan konsep hunian sementara dan menjelaskan secara detail prinsip dasar, desain dan bagaimana cara membangunnya. Nappi dan Souza (2017) mengembangkan konsep hunian sementara berbasis prinsip sustainable development dan humanitarian logistics. Sementara itu, Zhao dkk. (2017) membuat prencanaan hunian darurat untuk urban disaster reaulience menggunakan pendekatan integrated location-allocation model. Farouzandeh (2008), membuat beberapa petunjuk bagaimana cara mendesain hunian sementara untuk korban gempa berbasis partisipasi masyarakat. Selanjutnya beberapa berita media masa menginformasikan beberapa model hunian sementara berdasarkan material pembuatannya: Bangun rumah senyum di Lombok (www.tribunnews.com, 2018); Korban gempa Sulteng bisa huni 1200 hunian sementara (liputan6.com, 2018); Desain ciamik hunian sementara korban gempa buatan anak negeri (liputan6.com, 2018); ACT resmikan ICS di desa Gondang, Kecamatan Gangga, Lombok Utara (http//palembang.tribunews.com, 2018).

\section{METODE PELAKSANAAN}

\section{Solusi yang Ditawarkan}

Solusi yang ditawarkan melalui kegiatan pengabdian masayarakat ini untuk mengatasi kebutuhan hunian sementara masyarakat yang terdampak bencana gempa di Lombok adalah dengan menyediakan pilihan-pilihan desain huntara yang terbuat dari beberapa alternatif bahan. Salah satu desain tersebut nantinya akan dibuat menjadi 
prototipe bekerjasama dengan mitra konsultan yang selanjutnya diharapkan bisa digunakan secara luas oleh masyarakat.

\section{Target Luaran dan Khalayak Sasaran}

Luaran yang diharapkan adalah pilihan-pilihan alternatif desain hunian sementara yang cocok dengan karakter masyarakat Lombok. Sasaran kegiatan pengabdian kepada masyarakat ini adalah warga masyarakat yang terdampak oleh gempa Lombok tahun 2018. Kegiatan ini melibatkan pihak kampus sebagai pembuat desain, sebuah perusahan konsultan profesional dan pemerintah daerah. Dengan demikian ada empat pihak yang terkait dalam kegiatan ini; kampus sebagai lembaga pendidikan, konsultan sebagai lembaga professional, pemerintah daerah sebagai pemegang kebijakan dan masyarakat sebagai pengguna akhir.

\section{HASIL DAN PEMBAHASAN}

\section{Desain huntara lumbung Bambu}

Konsep huntara lumbung bambu ini dibuat denga mengadopsi rumah tradisional Lombok yang berbentuk lumbung menggunakan bahan kayu usuk dan pipa paralon dengan dinding anyaman bambu (bedek). Teknik pembuatan cukup sederhana; semua kerangka bangunan terbuat dari kayu usuk 4/6 dan atap dari pipa pvc ukuran $3 / 4$ inchi. Atap dibuat dari karpet talang air yang disusun sedemikian rupa sehingga berfungsi sebagai atap. Dinding bangunan terbuat dari anyaman bambu. Luas rumah adalah $3 \times 3$ meter untuk panjang dan lebar serta tinggi 2,5 meter. Lantai terbuat dari tanah urug yang sekelilingnya diberi pasangan bata setinggi $20 \mathrm{~cm}$ dan bagian atas dilapisi campuran pasir dan semen. Konsep hunian sementara berbentuk lumbung bambu ini dapat dilihat pada Gambar 1.

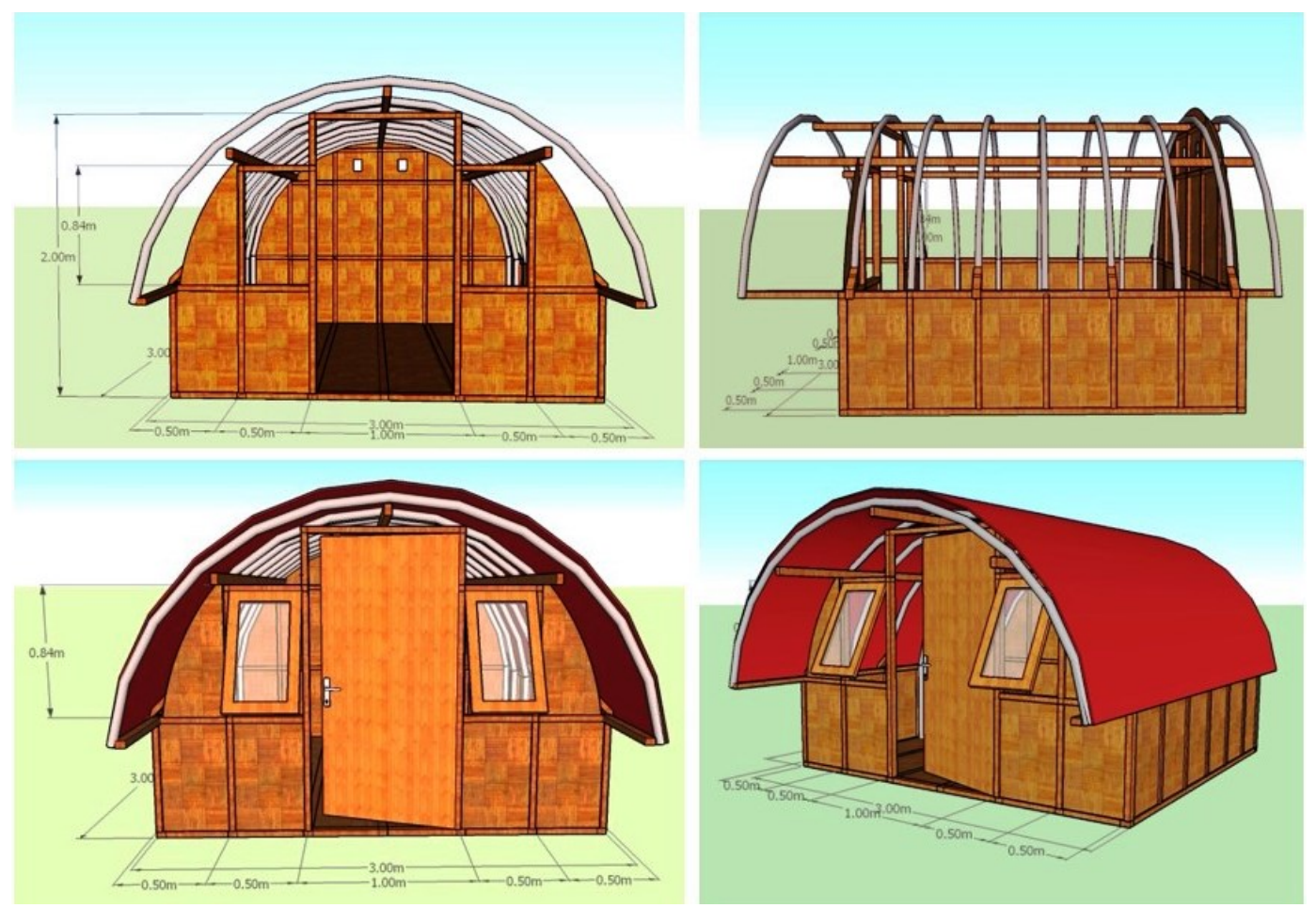

Gambar 1. Sketsa konsep hunian sementara lumbung bambu 
Hunian ini dikembangkan dengan konsep panel dimana masing-masing bagian bangunan dibuat secara terpisah kemudian digabung menjadi satu kesatuan. Konsep ini memungkinkan bangunan dibuat secara massal di workshop kemudian dibawa dalam bentuk panel terpisah dan dirakit dilokasi. Tahapan pembuatannya dimulai dengan merakit kerangka dinding dari bahan kayu usuk ukuran $4 / 6 \mathrm{~cm}$ yang disambung dengan pelat yang terbuat dari potongan lembaran plywood seperti yang diperlihatkan pada Gambar 4.4. Mengingat bahwa bangunan ini hanya bersifat sementara, maka kayu yang digunakan cukup dari kayu-kayu kelas rendah yang biasa dipakai untuk membuat bekisting.Setelah panel kerangka masing-masing bagian dindingnya terbentuk, maka selanjutnya dilakukan perangkaian menjadi sebuah struktur kerangka bangunan utuh. Perlu diperhatikan bahwa ketika memasang masing-masing bagian kerangka ini, pada setiap pertemuan sudut disambung atau dihubungkan dengan batang diagonal sehingga kerangka bangunan menjadi lebih kaku dan tidak bergerak ketika dogoyangkan.

Langkah selanjutnya adalah memasang kerangka atap yang terbuat dari pipa paralon ukuran $1 / 2$ inchi yang sebelumnya dilengkungkan terlebih dahulu. Untuk mencegah masuknya air, maka pipa paralon disatukan dengan kerangka kayu menggunakan klem dengan sambungan sekrup. Pipa paralon disatukan dengan kerangka dinding bagian bawah sampai di lantai dasar sehingga terdapat overlap antara kayu dengan pipa sepanjang $50 \mathrm{~cm}$. Sambungan overlap ini dimaksudkan untuk menjadi penyangga bagi pipa ketika dilengkungkan sehingga bisa terbentuk lengkungan yang sempurna. Penyambungan antar pipa dengan kayu usuk bisa juga dilakukan dengan cara diikat. Pipa dipasang pada setiap jarak $50 \mathrm{~cm}$. Setelah semua bagian kerangka bangunan terpasang, maka langkah selanjutnya adalah membuat bagian penutup, baik penutup dinding maupun penutup atap. Bahan yang digunakan sebagai penutup dinding adalah anyaman bambu atau yang disebut dengan bedek. Proses pemasangan dilakukan dengan memotong bedek bambu sesuai dengan ukuuran panel kerangka dinding dan kemudian ditempelkan ke kerangka dinding yang sudah disiapkan.

Sampai pada tahap ini, bangunan sudah siap dipasang dilokasi. Langkah selanjutnya adalah mempersiapkan lantai tempat bangunan ini diletakan. Lantai dibuat dari pasangan rollag bata keliling yang kemudian diisi dengan tanah urugan. Bisa juga diisi dengan pasir atau material lain seperti kapur. Setelah dipadatkan, lantai ditutup dengan mortar (campuran semen dan pasir) dengan perbandingan 1:8 dan dihaluskan bagian permukaannya. Setelah bagian lantai siap, maka tahapan selanjutnya adalah meletakan bangunan pada lantai yang sudah disiapkan tersebut. Bagian bangunan disatukan dengan lantai menggunakan klem besi yang diangkurkan dengan baut. Cara lain juga bisa digunakan, misalnya dengan langsung memasang baut pada usuk kayu paling bawah dari rangka dinding ke lantai. Sistem sambungan ini bersifat sementara dengan maksud apabila sudah saatnya diganti dengan bangunan permanen, bisa dilepaskan kembali dan dimanfaatkan untuk keperluan lain.

Setelah semua bagian dirangkai pada posisinya, maka tahapan terakhir adalah memasang daun jendela dan pintu. Daun jendela bisa dibuat dari bahan apa saja yang murah, misalnya menggunakan plywood atau bahkan lembaran tripleks biasa. Bagian tengah dari jendel cukup ditutup dengan lembaran plastic transparan yang agak tepal untuk memungkinkan pencahayaan alami sehingga tanpa membuka jendela pun, cahaya bisa masuk kedalam bangunan. Daun pintu pun demikian, bisa dibuat dari bahan yang murah dan harus ringan. Kerangka bangunan terbuat dari kayu usuk yang tidak terlalu besar sehingga pintu harus dibuat dari bahan yang ringan supaya bisa berfungsi dengan baik selama waktu pemakaian. Penggunaan bedek bambu yang mempunyai banyak kisi- 
kisi memungkinkan udara bersirkulasi dengan baik. Prototipe bangunan yang sudah jadi dapat dilihat pada Gambar 2.

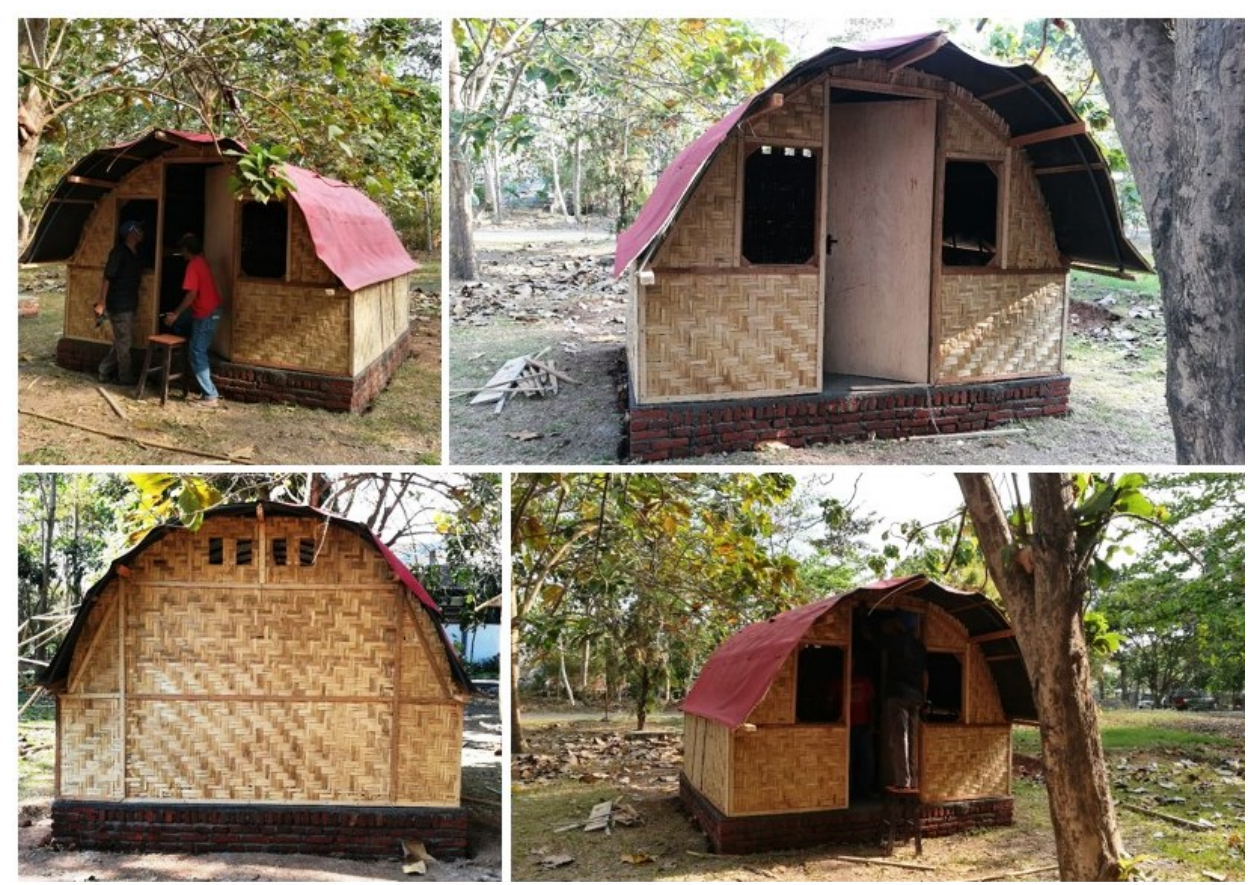

Gambar 2. Prototipe hunian sementara yang sudah siap dihuni

Estimasi biaya untuk membuat hunian ini sekitar Rp. 6,5 juta,- dengan asumsi bahwa semua bahan dibeli termasuk ongkos tukang. Rincian Rancangan Anggaran Biaya (RAB) diperlihatkan pada Tabel 1.

Tabel 1. Estimasi biaya pembuatan huntara lumbung bambu

\begin{tabular}{clr}
\hline No & \multicolumn{1}{c}{ Jenis Pekerjaan } & Jumlah \\
\hline 1 & Pekerjaan tanah & 200,000 \\
2 & Pekerjaan pasangan/lantai & 300,000 \\
3 & Pekerjaan rangka & $2,500,000$ \\
4 & Pembuatan pintu & 750,000 \\
5 & Pekerjaan dinding & $1,000,000$ \\
6 & Pekerjaan atap & $1,250,000$ \\
7 & Pekerjaan finishing & 500,000 \\
\hline & Jumlah Total & $6,500,000$ \\
\hline
\end{tabular}

\section{Desain Huntara lumbung Spandek-Plywood}

Sama seperti desain sebelumnya, konsep hunian sementara yang kedua ini juga dikembangkan berbasis rumah tradisional masyarakat Lombok, tetapi menggunakan bahan yang berbeda yakni spandek sebagai material yang dominan untuk bagian atapnya dan plywood sebagai dinding dan pintu. Material spandek ini sedang popular dan tersedia dalam jumlah yang cukup dan mudah diangkut dalam jumlah besar karena ringan. Luas rumah adalah $3 \times 3$ meter untuk panjang dan lebar, dan tinggi 2,8 meter. Lantai terbuat dari tanah urug yang sekelilingnya diberi pasangan bata setinggi $20 \mathrm{~cm}$ dan bagian atas dilapisi campuran pasir dan semen. Dinding terbuat dari plywood $5 \mathrm{~mm}$. 
Hunian ini didesain dan dikembangkan bersama dengan pihak ketiga, QIU, sebuah perusahaan yang dimiliki oleh alumni JTS. Konsep desain dari hunian sementara dari bahan spandek plywood ini ditampilkan pada Gambar 3.
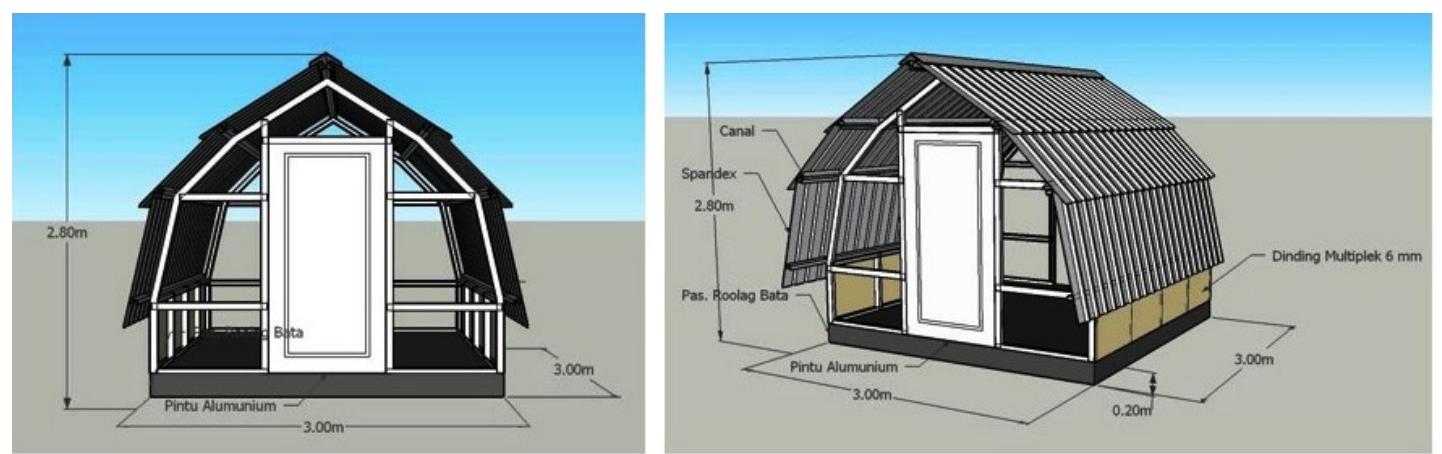

Gambar 3. Konsep desain hunian sementara dari bahan spandek/plywood

Kerangka utama bangunan dibuat dari bahan baja ringan dengan pertimbangan untuk kemudahan transportasi dan pemasangan. Dinding terbuat dari material plywood yang langsung disatukan dengan kerangka baja sebagai panel-panel terpisah yang bisa dirangkai dilapangan. Pembuatan kerangka dan pemasangan plywood sebagai panel dilakukan di workshop mitra kerjasama. Proses persiapan bahan dan pembuatan panel ini memerlukan waktu 3 hari dengan tenaga kerja sebanyak 3 orang. Salah satu prototipe desain dibangunkan langsung dilokasi korban gempa. Setelah semua proses persiapan lahan, perakitan sampai akhirnya finishing selesai dilakukan, maka selanjutnya hunian sementara tersebut diserahkan kepada warga oleh Dekan Fakultas Teknik Universitas Mataram seperti yang terlihat pada Gambar 4.

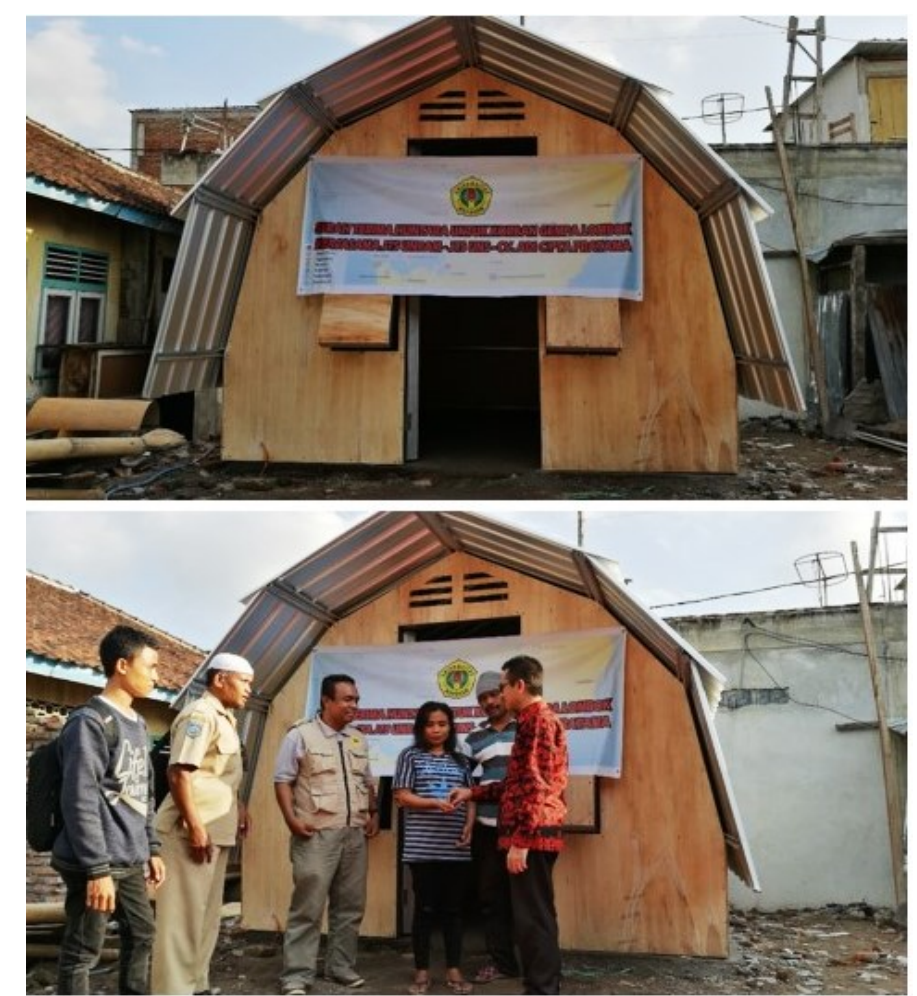

Gambar 4. Penyerahan hunian sementara kepada warga penerima bantuan 
Estimasi biaya untuk membuat hunian ini sekitar Rp. 10 juta,- dengan asumsi bahwa semua bahan dibeli termasuk ongkos tukang. Rincian Rancangan Anggaran Biaya (RAB) diperlihatkan pada Tabel 2.

Tabel 2. Estimasi biaya pembuatan huntara lumbung spandek/plywood

\begin{tabular}{clr}
\hline No & \multicolumn{1}{c}{ Jenis Pekerjaan } & Jumlah \\
\hline 1 & Pekerjaan tanah & 200,000 \\
2 & Pekerjaan pasangan/lantai & 300,000 \\
3 & Pekerjaan rangka & $3,500,000$ \\
4 & Pembuatan pintu & 750,000 \\
5 & Pekerjaan dinding & $2,000,000$ \\
6 & Pekerjaan atap & $2,750,000$ \\
7 & Pekerjaan finishing & 500,000 \\
\hline & Jumlah Total & $10,000,000$ \\
\hline
\end{tabular}

\section{KESIMPULAN}

Kegiatan pengabdian pada masyarakat dengan topik pengembangan desain dan prototipe hunian sementara untuk masyarakat terdampak gempa Lombok telah terlaksana dengan baik. Kegiatan tersebut dilaksanakan dengan metode pengembangan dan analisis desain dan pembuatan prototipe dikampus maupun dilapangan. Kegiatan ini terselenggara atas kerjasama Magister Teknik Sipil Fakultas Teknik Universitas Mataram dengan Konsultan Adi Cipta Pratama.

\section{DAFTAR PUSTAKA}

[1]. Anonim, 2018, Bangun rumah senyum di Lombok, diakses pada laman: www.tribunnews.com

[2]. Anonim, 2018, ACT resmikan ICS di desa Gondang, Kecamatan Gangga, Lombok Utara, diakses pada laman: http//palembang.tribunews.com.

[3]. Anonim, 2018, Korban gempa Sulteng bisa huni 1200 hunian sementara di Desember 2018, diakses pada laman: www.liputan6.com.

[4]. Anonim, 2018, Desain ciamik hunian sementara korban gempa buatan anak negeri, diakses pada laman: www.liputan6.com.

[5]. Abulbour, A. H. (2014). The Post-Disaster Temporary Dwelling: Fundamentals of Provision, Design and Construction. HRBC Journal, Vol. 10, pp. 10-24.

[6]. Forouzandeh, A. J., Hosseini, M., dan Sadeghzadeh, M. (2008). Guidelines for Design of Temporary Shelters After Earthquake Based on Community Participation, The $14^{\text {th }}$ World Conference on Earthquake Engineering, October 12-17, 2008, Beijing, China.

[7]. Nappi, M. M. L, dan Souza, J. C. (2017). Temporary Shelters: An Arcitectural Look at User-Environment Relationship, Arquteurarevista Journal, Vol 13/2, pp. 112-120.

[8]. Rohwerder, B. (2016). Transitional Shelter in Post-Disaster Context, Research Report, Applied Knowledge Services, www.ssdrc.org.

[9]. Zhao, L., Li, H., Sun, Y., Huang, R., Hu, Q., Wang, J., dan Gao, F. (2017). Planning Emergency Shelters for Urban Disaster Resilience: An integrated Location-Allocation Modeling Approach, Journal of Sustaibaility, Vol 9. 